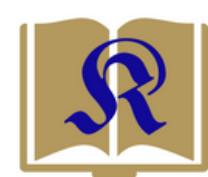

KURIOS
KURIOS

(Jurnal Teologi dan Pendidikan Agama Kristen)

ISSN 2615-739X (print), 2614-3135 (online)

Vol. 4, No. 2, Oktober 2018 (157-166)

http://www.sttpb.ac.id/e-journal/index.php/kurios

\title{
Mengaktualisasikan Amanat Agung Matius 28:19-20 dalam Konteks Era Digital
}

\author{
Handreas Hartono \\ Sekolah Tinggi Teologi Pelita Bangsa Jakarta \\ handreas@sttpb.ac.id
}

\begin{abstract}
Great comission is a mandate that Jesus gave to His disciples before He ascent to the heaven. This mandate often been implemented to be a mere activity of evangelization, how to make people believe in Jesus for their salvation sake. The world where church lived today has changed by applying advanced technology in all human life aspect, for generally called as the era of digitalization. There were some different challenges and needs of today's church with the early church who received that mandate in first century. Thus this is an article aimed to explain how to actualize a great comission according Matthew 28:19-20 in a different world today, which called the era of digital. This article used a qualitative method with an analysis approach to the text of Matthew 28:19-20, and a desriptive of the era of digital today as a context of actualizing that great comission. As a conclucion, church ought to apply the advanced technology with digilization to reach out people in the world where unreached yet.
\end{abstract}

\begin{abstract}
Abstrak
Amanat agung merupakan sebuah mandat yang Yesus berikan kepada murid-murid-Nya sebelum Ia naik ke surga. Perintah ini sering diimplementasikan dengan sekadar tindakan penginjilan, bagaimana membuat orang menjadi percaya Yesus demi keselamatannya. Dunia di mana gereja hidup sekarang telah berubah oleh karena kemajuan teknolgi yang merambah seluruh aspek hidup manusia, yang biasa disebut dengan era digitalisasi. Oleh sebab itu ada perbedaan tantangan dan kebutuhan yang dialami oleh gereja sekarang dengan gereja mula-mula di abad pertama. Maka dengan demikian, artikel ini bertujuan untuk menjelaskan bagaimana mengaktualisasikan amanat agung dalam Matius 28:19-20 dalam konteks dunia di era digital. Artikel ini merupakan penelitian kualitatif dengan pendekatan analisis atas teks Matius 28:19-20, dan deskriptif atas konsep dunia di era digital sebagai konteks untuk mengaktualisasikan amanat agung tersebut. Sebagai kesimpulan, gereja harus mengaplikasikan kemajuan teknologi digitalnya untuk menjangkau orang-orang yang selama ini belum terjangkau.
\end{abstract}

Article History

Submit:

09 October 2018

Revised:

20 October 2018

Accept:

29 October 2018

Keywords:

great comission; mandate; the era digital; Matthew 28:19-20; church ministry

Kata kunci: amanat agung; mandat; era digital; Matius 28:19-20; pelayanan gereja 


\section{Pendahuluan}

Amanat agung merupakan bagian penting dalam kehidupan kekristenan atau gereja. Salah satu faktor pertumbuhan gereja (secara kuantitatif) adalah dengan melaksanakan amanat agung. Gereja yang melaksanakan amanat agung merupakan gereja yang dinamis, terus bertumbuh dan berkembang. Selain itu, amanat agung merupakan hakikat dari tugas dan panggilan gereja dalam dunia yang tidak boleh diabaikan. ${ }^{1}$ Ini merupakan tugas yang tidak dapat ditolak oleh semua orang Kristen, karena sesuai dengan sifatnya, yakni sebuah amanat yang datangnya dari Yesus.

Amanat agung secara sederhana sering diartikulasikan dengan kegiatan penginjilan atau misi. Dan tidak jarang juga, sebagai konsekuensinya ini diatribusikan dengan pekerjaan para misionaris, yang pergi ke daerah-daerah pedalaman tertentu dengan mengadakan penginjlian sebagai bentuk langsung dari amanat agung itu sendiri. Amanat agung diasumsikan sebagai kegiatan pergi menginjili atau membuat orang menjadi percaya kepada Tuhan Yesus, dan sebagai buah atau hasil pelayanan itu orang tersebut menjadi bertobat, yang secara teknis diartikulasikan dengan berpindah agama. Hal tersebut tidaklah salah, karena kegiatan amanat agung secara prinsip adalah membuat seseorang percaya kepada Yesus sebagai Tuhan, sebagai syarat keselamatan hidupnya.

Pembahasan amanat agung dalam kajian teologis bukanlah merupakan hal yang baru, melainkan sebuah tema yang terus-menerus diangkat dalam banyak kegiatan gerejawi. Karena sejatinya eksistensi dan esensi gereja tidak dapat dipisahkan dari kegiatan ini. Hanya saja seringkali amanat agung menjadi sebuah pembahasan yang monoton tentang bagaimana pergi ke sebuah daerah dan tempat, lalu mengadakan penginjilan atau kegiatan Kebaktian Kebangunan Rohani, dan membuat orang lain menjadi Kristen dengan cara mereka menerima Yesus. Kegiatan ini telah menjadi stigma di kalangan orang-orang non-Kristen, dianggap sebagai kegiatan kristenisasi. Stigma ini tidak mudah pudar apalagi hilang begitu saja, sekalipun sejatinya persoalan percaya Yesus tidak semudah sekadar menjadi seorang Kristen.

Tidak jarang pola penaklukkan wilayah di masa lalu menjadi salah satu cara mengembangkan konsep agama yang dianut oleh orang-orang yang menaklukkan wilayah itu. Cara ini pun yang tidak jarang digunakan dalam pola pemberitaan injil di zaman atau abad pertengahan hingga ke masa modern. Pemberitaan injil seringkali datang bersamaan dengan proses invasi wilayah kekuasaan atau teritorial politis. Keadaan ini yang tumbuh subur di

\footnotetext{
${ }^{1}$ Ralph Martin, Evangeism and Theologian (Grand Rapids: Zondervan Publishing House, 1973), 65
} 
konteks Indonesia, kekristenan datang bersamaan dengan penjajahan; dan agama Kristen menjadi sebuah stigma agama penjajah.

Perlu adanya sebuah proses rekonstruksi konsep amanat agung untuk mengaktualisasikan kegiatan ini dalam konteks yang kekinian, dalam sebuah era yang sudah jauh berkembang dari masa-masa di mana pesan tentang amanat agung dikumandangkan pertama kali. Selama ini kegiatan amanat agung hanya pada konsep yang konvensional yang diturunkan dari generasi ke generasi berikutnya, yaitu pesan tentang menjadikan orang yang belum mengenal Yesus menjadi percaya; dengan kesan yang tertinggal adalah sebuah stigma proses kristenisasi.

Konsep amanat agung dalam Matius 28:19-20 juga perlu dikaji dan dipahami ulang dalam konteks yang lebih kekinian, agar tidak terjadi sebuah kontradiksi budaya. Konsep amanat agung tidak lagi diimplemetasikan dalam suasana yang sudah berlalu, melainkan pada tatanan sekarang di mana gereja sedang bergumul pada budaya yang tercipta oleh zamannya. ${ }^{2}$ Proses dan implementasi amanat agung yang sesuai Matius 28:19-20 dimengerti secara substansial dan diaktualisasikan dalam konteks masa yang sedang berubah, dan menemukan bentuknya pada era digitalisasi sekarang ini. Artinya, amanat agung harus dipahami dalam konteks dan konsep era digital.

Penelitian sebelumnya yang berkaitan dengan tema ini adalah apa yang dilakukan oleh Harls Evan R. Siahaan tentang mengaktualisasikan pelayanan sesuai dengan karunia yang fit pada masa atau era digital. ${ }^{3}$ Implikasi dari amanat agung sejatinya terjadi pada pelayananpelayanan yang tidak hanya sekadar berkutat pada kegiatan penginjilan belaka, karena gereja juga perlu melakukan fungsi yang lain. Dalam pembahasan yang dilakukan oleh Siahaan, menekankan adanya pengembangan karunia dalam melayani sesuai dengan tantangan dunia di mana gereja berada. Gereja perlu melakukan semacam reposisi pemikiran kepada warga gereja atau jemaat yang dilayani. ${ }^{4}$ Sehingga dalam capaiannya, gereja tidak monoton untuk mengaktualisasikan esensi amanat agung tersebut.

Ada beberapa kata kunci yang perlu diperhatikan pada konsep amanat agung dalam Matius 28:19-20, yakni beberapa kata kerja, seperti: pergi, memuridkan, membaptis dan mengajarkan. Kata-kata kerja ini menjadi semacam indikator dalam upaya

\footnotetext{
${ }^{2}$ Jelita Sihite, "Berteologi Dan Melayani," KURIOS (Jurnal Teologi dan Pendidikan Agama Kristen) 1, no. 1 (2013): 67-75, www.sttpb.ac.id/e-journal/index.php/kurios.

${ }^{3}$ Harls Evan R. Siahaan, “Aktualisasi Pelayanan Karunia Di Era Digital," EPIGRAPHE: Jurnal Teologi dan Pelayanan Kristiani 1, no. 1 (2017): 23-38, www.stttorsina.ac.id/jurnal/index.php/epigraphe.

${ }^{4}$ Kevin Tonny Rey, "Konstruksi Teologi Dalam Konteks Reposisi Pemikiran Warga Gereja," EPIGRAPHE: Jurnal Teologi dan Pelayanan Kristiani 2, no. 1 (2018): 1-13, www.stttorsina.ac.id/jurnal/index.php/epigraphe.
} 
mengimplementasikan atau mengaktualisasikan kegiatan amanat agung itu sendiri. Artinya, amanat agung tidak boleh sekadar diartikulasikan sebatas kegiatan penginjilan, namun sebuah rangkaian pelayanan yang di dalamnya memuat kegiatan penginjilan.

Inti dari amanat agung sejatinya adalah sebuah kegiatan pemuridan (Yunani: $\mu \alpha \theta \eta \tau \varepsilon \dot{\sigma} \sigma \tau \varepsilon)$. Pemuridan dapat berimplikasi pada kegiatan penginjilan seperti yang dimengerti secara umum, yakni membuat orang menjadi percaya. Namun pemuridan juga dapat diimplementasikan dalam bentuk pengajaran atau mendorong seseorang untuk melakukan pelayanan, apa pun bentuk dan segmentasinya. ${ }^{5}$ Amanat agung tidak hanya dititikberatkan pada kegiatan penginjilan semata, walaupun sejatinya ini bagian dari pelayanan, namun pada bentuk yang lebih luas, termasuk dalam mengajarkan jemaat dan mendorong mereka untuk terlibat dalam pelayanan. ${ }^{6}$ Semua hal tersebut harus dilihat dalam satu bingkai rangkaian amanat agung.

Gereja saat ini ada dalam sebuah dunia yang emmasuki era digital. Pengertian era digital tidak lepas dari konsekuensi dari kemajuan teknologi digitalisasi yang telah mengubah banyak asepk hidup manusia. Digitalisasi adalah proses di mana semua bentuk informasi baik angka, kata, gambar, suara, data, atau gerak dikodekan ke dalam bentuk bit (binary digit atau yang biasa disimbolisasikan dengan representasi 0 dan 1) yang memungkinkan manipulasi dan transformasi data (bitstreaming). ${ }^{7}$ Tantangan dan kebutuhan yang ada pada era digital sekarang ini berbeda dengan masa di mana para rasul menerima mandat amanat agung, sehingga konsep amanat agung harus dipahami atau diaktualisasikan dalam keadaan dunia sekarang ini.

Penelitian ini bertujuan untuk menjelaskan sebuah konsep amanat agung yang harus dipahami dalam konteks era digital masa kini, di mana gereja ada dan menggumuli keberadaannya untuk mengaktualisasikan amanat agung, tanpa harus mengabaikan kata-kata kunci yang ada di dalamnya sebagai indikator kegiatan amanat agung itu sendiri. Sehingga, pada akhirnya diperoleh sebuah rekomendasi konsep aktual penerapan amanat agung dalam era digital.

\footnotetext{
${ }^{5}$ Agustin Soewitomo Putri, "Dukungan Terhadap Anggota Keluarga Lansia Dalam Melayani," EPIGRAPHE: Jurnal Teologi dan Pelayanan Kristiani 1, no. 2 (2017): 73-90, www.stttorsina.ac.id/jurnal/index.php/epigraphe.

${ }^{6}$ Harls Evan R. Siahaan, "Karakteristik Pentakostalisme Menurut Kisah Para Rasul,” DUNAMIS: Jurnal Teologi dan Pendidikan Kristiani 2, no. 1 (2017): 12-28, www.sttintheos.ac.id/e-journal/index.php/dunamis.

${ }^{7}$ AG. Eka Wenats Wuryantai, "Digitalisasi Masyarakat: Menilik Kekuatan Dan Kelemahan Dinamika Era Informasi Digital Dan Masyarakat Informasi," Jurnal ILMU KOMUNIKASI 1, no. 2 (November 27, 2013), accessed Mei 21, 2015, http://ojs.uajy.ac.id/index.php/jik/article/view/163.
} 


\section{Metodologi}

Ini merupakan sebuah penelitian kualitatif-deskriptif yang menjelaskan konsep amanat agung dalam Matius 28:19-20 dengan sebuah latar depan yang berbeda dengan apa yang ada di masa lalu, di mana menjadi latar belakang nas itu. Perkataan Yesus di masa awal peradaban Masehi tidak selalu harus dipahami seperti pada masanya, karena setiap peristiwa dan teks tidak lepas dari konteks yang melingkupinya. Para pembaca perlu memahami adanya sebuah benang merah dari masa nas tersebut lahir hingga dilakukan pada masa kini.

Sebuah pendekatan analisis kata dan konsep digunakan untuk menjelaskan dan memahami kata-kata kunci sebagai indikator amanat agung dalam nas tersebut. Kata-kata dalam pola imperatif, seperti: "pergilah", "jadikanlah...murid”, "baptislah", dan "ajarkanlah" menjadi indikator sekaligus kata kunci dalam memahami amanat agung secara utuh. Amanat agung bukan hanya sekadar pergi menginjil ke semua tempat, namun juga tentang bagaimana memuridkan dan mengajarkan. Amanat agung harus dipahami dalam semua konteks itu. Keempat kata kunci itu harus dijelaskan secara utuh pada konteksnya dan menerapkan pemahaman itu dalam kekinian sehingga amanat agung tidak dipahami secara parsial. Analisis kata ini digunakan untuk mengerti konsep amanat agung, baik secara gramatikal maupun teologisnya, sehuingga tidak harus kaku pada satu proses saja dalam memahami amanat agung.

Kata "pergilah" dalam ayat 19 menggunakan kata Yunani yakni poreuomai, yang secara harafiah berarti "pergi, berjalan" pada umumnya. Kata inilah yang umumnya diartikulasikan sebagai sebuah bentuk kegiatan yang pergi ke daerah-daerah tertentu, wilayah yang belum terjangkau Injil untuk melakukan kegiatan penginjilan. Menarik, bahwa kata pergi dalam ayat 19 di Alkitab Terjemahan Bahasa Indonesia (ITB) merupakan konsekuensi dari ayat sebelumnya. Mengawali ayat tersebut dengan frasa "karena itu", seakan memberikan indikasi bahwa kalimat selanjutnya disebabkan oleh kalimat sebelumnya. Ini berarti ayat 18 merupakan alasan untuk melakukan ayat 19. Meskipun frasa "karena itu" tidak mewakili kata apa pun dalam bahasa Yunaninya di ayat 19, namun hal tersebut tidak terlalu mengganggu tatanan yang ada di ayat tersebut.

Terjemahan Bahasa Inggris seperti KJV dan NIV menggunakan kata yang serupa, yakni "therefore", yang berarti sama "karena itu". Matius 28:18 merupakan sebuah pernyataan Yesus, bahwa kepada-Nya telah diberikan segala kuasa, dan ayat selanjutnya dianggap sebagai tindakan lanjut dari sebuah pernyataan yang muncul dalam ayat 18 tersebut. Namun demikian, ada atau tidaknya preposisi tersebut, tidak boleh mengubah makna atau 
prinsip dalam ayat tersebut. Tentunya kata kunci awal ini berperan untuk memberikan pemahaman kepada pembacanya untuk melakukan apa.

Kata kunci kedua, “jadikanlah semua bangsa murid-Ku”, atau yang biasa diwakili dengan kata yang lebih sederhana "muridkanlah", memberikan pengertian bahwa pendengar pada saat itu harus melakukan sebuah kegiatan pemuridan. Kata kerja pertama memberikan maksud untuk apa seseorang pergi, yakni melakukan pemuridan. Kata kuncinya adalah pemuridan, sehingga proses ini yang harus mendapatkan artikulasi dan implikasi tindakan pelayanan dalam konteks kekristenan atau gereja saat ini. Mungkin bisa dikatakan ini jugalah yang menjadi inti dari amanat itu sendiri, melakukan pemuridan.

Kata "pemuridan" dalam bahasa Yunani memiliki arti mengajar, yang berarti hal ini berkaitan dengan dunia pendidikan (edukasi). Kegiatan pemuridan melibatkan dua pihak, guru dan murid $^{8}$, sehingga proses tersebut dapat terlaksana untuk mewujudkan aktivitas amanat agung. Penginjilan dalam hal ini harus dilihat sebagai bagian dari proses pemuridan, atau sesungguhnya inilah esensi dari istilah "penginjilan" yang digunakan selama ini. ${ }^{9}$ Pastinya, amanat agung harus dilihat dari kacamata yang lebih komprehensif dari sekadar kegiatan penginjilan, di mana pelayanan memberikan wadah untuk mengekspresikannya.

Kata kunci berikut adalah "baptislah", sebagai bentuk kelanjutan dari sebuah proses pemuridan. Kata "baptis" tidak menunjukkan teknis atau metode seperti apa, karena muridmurid atau para pendengar saat itu mengerti bagaimana harus menindaklanjuti perintah itu. Yang penting di sini adalah proses baptisan terjadi setelah adanya pemuridan. Bisa saja proses pemuridan di sini belum sepenuhnya selesai, karena sejatinya pemuridan terjadi secara terusmenerus, sehingga baptisan tidak dianggap sebagai akhir dari proses tesebut. Karena setelah itu ada proses berikutnya, yaitu "ajarkanlah", sebagai kata kunci berikut. Kata "ajarkan" merupakan sebuah bentuk yang mengikuti pemuridan dan baptisan. Artinya, mereka yang baru menjadi murid mendapatkan pengajaran (indoktrinasi) setelah melewati proses dijadikan murid dan dibaptis.

Pendekatan analisis kata untuk memahami konsep dan prinsip amanat agung dengan mempertimbangkan keadaan zaman yang berbeda dari penerima pertama dari amanat tersebut dengan keadaan sekarang di mana gereja menerima mandat itu menjadi sebuah pembahasan dalam penelitian ini. Itu sebabnya metode deskriptif digunakan untuk menggambarkan

\footnotetext{
${ }^{8}$ John R.W. Stott, The Radikal Disciple: Murid Yang Radikal (Jawa Timur: Literatul Perkantas, 2010), $11-12$

${ }^{9}$ Daniel Sutoyo, “Gaya Hidup Gereja Mula-Mula Yang Disukai Dalam Kisah Para Rasul 2: $42-47$

Bagi Gereja Masa Kini,” Jurnal Antusias 3, no. 6 (2014): 1-31, accessed Desember 26, 2017,

http://www.sttintheos.ac.id/e-journal/index.php/antusias/article/view/7.
} 
konteks penerima pesan atau amanat itu dan mengaktualisasikannya dalam konteks kekinian, yaitu dalam era digital.

\section{Analisis dan Pembahasan}

Persoalan utama dalam penelitian ini adalah tentang memahami konten dan prinsip amanat agung dalam perspektif dan konteks kekinian. Konteks kekinian yang dimaksud adalah masa postmodernisme dengan segala kemajuan teknologinya yang juga telah berimbas pada pergeseran nilai-nilai hidup, termasuk budaya dan pola beragama. ${ }^{10}$ Nilai-nilai yang diajarkan pada masa silam, dengan interval waktu yang sangat panjang telah memberikan sebuah ruang sekaligus jurang dengan masa sekarang ini. Sehingga, perlu untuk melakukan semacam rekonstruksi demi memberikan pemahaman yang sesuai dengan konteks zamannya.

Amanat agung jangan lagi dipandang menjadi sebuah tindakan penginjilan belaka, melainkan sebuah proses di mana setiap orang bisa berkontribusi di dalamnya melalui pelayanan. ${ }^{11}$ Amanat agung merupakan sebuah istilah teknis untuk menggambarkan sebuah perintah, mandat atau amanat yang diberikan Yesus kepada murid yang tersisa sesaat sebelum Ia naik ke surga, agar para murid pergi dan melakukan pemuridan kepada siapa saja di segala bangsa. Amanat agung adalah sebuah paket yang dapat dibagi dalam beberapa fase. Tiap fase dalam amanat agung memberikan ruang untuk setiap karunia dikembangkan. ${ }^{12}$ Artinya, amanat agung tidak merekomendasikan sebuah peran single di sini, justru kolaborasi, bagaimana tiap pelayanan akan menjalankan fungsi karunianya dan bersinergi.

Amanat agung adalah wadah refleksi karunia yang saling melengkapi dalam melakukan pekerjaan Tuhan. Tiap fase dalam amanat agung dapat ditangani oleh masingmasing karunia dan bentuk pelayanan yang dimampukan. Penginjil bukanlah orang yang paling berjasa dalam proses amanat agung, karena memelihara dan mendewasakan seseorang bukanlah perkara yang mudah. Dan pekerjaan merawat pun menjadi bagian dari amanat agung, ketika gereja memelihara mereka tetap ada dalam koridor iman Kirsten melalui pengajaran yang benar dan sehat.

\section{Implikasi "Pergilah"}

Kata pergi dalam Matius 28:19 harus dimaknai sebagai sebuah permulaan aktivitas dalam pemuridan. Frederick Kenyon menanggapi istilah "pergilah" yang dikaitkan dengan

\footnotetext{
${ }^{10}$ Sonny Eli Zaluchu, "Mengkritisi Teologi Sekularisasi," KURIOS (Jurnal Teologi dan Pendidikan Agama Kristen) 4, no. 1 (2018): 26-38, www.sttpb.ac.id/e-journal/index.php/kurios.

${ }^{11}$ Desti Samarenna, "Rahasia Allah Dalam Pelayanan Paulus Menurut Efesus 3 : 8-13," EPIGRAPHE: Jurnal Teologi dan Pelayanan Kristiani 2, no. 1 (2018): 8-13, http://www.stttorsina.ac.id/jurnal/index.php/epigraphe.

12 Siahaan, "Aktualisasi Pelayanan Karunia Di Era Digital."
} 
kegiatan penginjilan: "Evangelism must be grow. They have throught out from the additionaly. They have make move, and they have to make it progress, whatever done. Christ just not tell about go and finish, but he tell to move and make progress in abundantly." ${ }^{13}$ Pergi tidak hanya dimaknai dengan pergi ke suatu tempat atau daerah, melainkan bergerak dan membuat aktivitas. Beranjak dari keadaan sekarang, dan buatlah sebuah aktivitas dengan kreativtias tentunya, untuk memulai sebuah kegiatan selanjutnya, yakni pemuridan.

Pergi adalah perintah atau amanat agar para murid, di masa yang sekarang membuat sebuah terobosan atau aktivitas untuk pemuridan. Namun juga harus tetap memaknai pemahaman dasarnya, yakni pergi ke sebuah tempat atau mengunjungi sebuah daerah. Hanya saja pergi mengunjungi daerah-daerah tertentu tidak lagi harus dalam konsep masa lalu, sampai dan ada di tempat yang ingin dituju. Teknologi yang semakin maju telah membuat jarak semakin dekat dan makin mudah mengunjunginya.

Akses ke segala tempat tidak lagi sesulit masa lalu, di mana orang harus ada di tempat itu. Orang-orang dapat mengunjungi daerah-daerah yang jauh dengan bantuan teknologi, terutama lewat layanan internet. Perintah pergi untuk orang-orang yang ada pada masa yang dikenal dengan era digitalisasinya berarti juga mengunjunginya lewat bantuan teknologi digitalnya. Gereja bisa hadir di mana saja merambah setiap tempat dan wilayah di seluruh nusantara, bahkan dunia untuk memberikan proses pemuridan.

\section{Pelayanan Digital dan Digitalisasi Pelayanan}

Konsep pemuridan di masa era digital tidak lagi harus sekonvensional dulu, di mana pada saat ini orang dengan mudah dihubungkan (sekaligus dipisahkan) oleh teknologi digital. Pemuridan dapat dilakukan melalui pengadopsian atau pemanfaatan teknologi yang sesuai dengan kebutuhan gereja serta dunia pelayanan. Gereja tidak sekadar mengikuti arus namun lebih kepada memanfaatkan sebagai media.

Setiap zaman memiliki kebutuhannya masing-masing, sehingga gereja harus dapat membacanya sebagai kesempatan untuk menciptakan peluang dalam melayani. Jadikan murid atau memuridkan berarti menciptakan sebuah proses dialogis antara seorang guru dan murid; ada komunikasi yang tentu menjadi ikon kehidupan di era digital. Pemuridan di era digital tidaklah perlu dipaksakan dalam bentuk-bentuk konvensional. Gereja harus fleksibel dan update, berupaya melakukan digitalisasi pelayanan, sehingga dapat menjawab sebuah kebutuhan rohani di sana.

\footnotetext{
${ }^{13}$ Frederick Kenyon, The Ancient (New York: Harper and Brothers Publisher, 1940), p. 128
} 
Pergilah dapat dimaknai secara konteks era digital sebagai bentuk mengarungi (browse) samudra atau dunia internet. Gereja harus cepat mejawab tantangan dan kebutuhan ini, karena jika tidak akan tertinggal dengan gerak atau percepatan dunia yang semakin melaju. Pergilah bermakna pada bagaimana gereja saat ini melakukan kegiatan pemuridan dengan menghampiri melalui "dunia” melalui kemajuan teknologi yang ada.

Selain itu, komponen lain dalam amanat agung seperti pengjaran mendapatkan porsi yang signifikan dalam penggunaan kemajuan teknologi dan digitalisasi. Pelayanan pengajaran tidak lagi menggunakan format konvensional yang hanya berkutat pada pola printing-oriented melainkan menggunakan produk-produk digitial yang sudah dapat dirasakan menyentuh seluruh aspek hidup manusia. Kemajuan teknologi harus dibarengi dan diimbangi dengan program-program aplikatif yang dapat memuat nilai-nilai edukasi iman Kristen.

Amanat agung Matius 28:18-20 tidak lagi dipahami sesempit hanya melakukan tindakan penginjilan semata ${ }^{14}$, sekalipun penginjilan pun dapat mengadopsi penggunaan teknologi digital sebagai media penyampaian berita baik. Orang-orang Kristen harus mampu bersinergi dengan kekuatan jemaat awam yang pakar dalam bidang teknologi, untuk membangun sebuah bentuk pelayanan yang menggunakan teknologi ini. Gereja dapat menggandeng semua kekuatan jemaat yang memiliki basis pengetahuan dan ilmu (kemampuan) penggunaan teknologi untuk membangun bahkan menciptakan bentuk-bentuk pelayanan yang berorientasi pada teknologi digital.

Daerah-daerh perbatasan bahkan hingga pelosok dan pedalaman bukan lagi menjadi wilayah yang asing terhadap internet. Jangkauan yang begitu luas telah memberikan sebuah peluang terbentuknya sebuah budaya masyarakat yang tidak lagi berorientasi pada alat-alat tradisional, bahkan dalam konteks beribadah. Jangkauan internet yang telah menembus semua sekat-sekat yang sulit dijangkau membuat pelayanan dalam rangka mengaktualisasikan amanat agung dapat dilakukan dengan maksimal.

Pada akhirnya, aktualisasi amanat agung dalam dunia kemajuan teknologi dan era digitalisasi harus memperhatikan esensi dari konseptual amanat agung tersebut, dan mempertimbangkannya dalam berbagai konsekuens perubahan zaman. Karena Alkitab berlaku bagi setiap zaman, namun tidak memaksakan sebuah konsep yang kontra perubahan dan pergeseran zaman di mana gereja ada dan hidup. Artinya, nilai-nilai konseptualisasi yang diejawantah dari teks masa lalu tetap harus mempertimbangkan pergeseran perubahan komponen zaman.

\footnotetext{
${ }^{14}$ Ian K Duffield and Urban Theology Unit, "Difficult Texts : Matthew 28. 19-20," Theology 120, no. 2 (2017): 108-111, journals.sagepub.com/home/tjx.
} 


\section{Kesimpulan}

Amanat agung bukanlah sebuah konsep yang harus dimaknai dengan kegiatan penginjilan senantiasa, melainkan sebuah paket atau fase di mana pemuridan menjadi inti dari serangkaian kegiatan tersebut. Sementara itu amanat agung yang diungkapkan Yesus pada masa lalu harus dimaknai dalam sebuah konteks yang sesuai dengan zaman di mana gereja berada. Pada masa era digital seperti ini, maka mengimplementasikan amanat agung adalah dengan menggunakan teknologi tersebut sebagai hamba untuk menyampaikan tema-tema pemuridan dan pengajaran sehingga setiap orang dapat mengenal Kristus melalui kemajuan digital yang ada.

\section{Referensi}

Kenyon, Frederick. The Ancient, New York: Harper and Brothers Publisher, 1940

Martin, Ralph. Evangeism and Theologian (Grand Rapids: Zondervan Publishing House, 1973

Duffield, Ian K, and Urban Theology Unit. "Difficult Texts : Matthew 28. 19-20." Theology 120, no. 2 (2017): 108-111. journals.sagepub.com/home/tjx.

Putri, Agustin Soewitomo. "Dukungan Terhadap Anggota Keluarga Lansia Dalam Melayani." EPIGRAPHE: Jurnal Teologi dan Pelayanan Kristiani 1, no. 2 (2017): 73-90. www.stttorsina.ac.id/jurnal/index.php/epigraphe.

Rey, Kevin Tonny. "Konstruksi Teologi Dalam Konteks Reposisi Pemikiran Warga Gereja." EPIGRAPHE: Jurnal Teologi dan Pelayanan Kristiani 2, no. 1 (2018): 1-13. www.stttorsina.ac.id/jurnal/index.php/epigraphe.

Samarenna, Desti. "Rahasia Allah Dalam Pelayanan Paulus Menurut Efesus 3 : 8-13." EPIGRAPHE: Jurnal Teologi dan Pelayanan Kristiani 2, no. 1 (2018): 8-13. http://www.stttorsina.ac.id/jurnal/index.php/epigraphe.

Siahaan, Harls Evan R. “Aktualisasi Pelayanan Karunia Di Era Digital.” EPIGRAPHE: Jurnal Teologi dan Pelayanan Kristiani 1, no. 1 (2017): 23-38. www.stttorsina.ac.id/jurnal/index.php/epigraphe.

_ . "Karakteristik Pentakostalisme Menurut Kisah Para Rasul.” DUNAMIS: Jurnal Teologi dan Pendidikan Kristiani 2, no. 1 (2017): 12-28. www.sttintheos.ac.id/ejournal/index.php/dunamis.

Sihite, Jelita. "Berteologi Dan Melayani." KURIOS (Jurnal Teologi dan Pendidikan Agama Kristen) 1, no. 1 (2013): 67-75. www.sttpb.ac.id/e-journal/index.php/kurios.

Sutoyo, Daniel. “Yesus Sebagai Guru Agung.” Jurnal Antusias 3, no. 5 (2014): 64-85. Accessed April 26, 2017. http://www.sttintheos.ac.id/ejournal/index.php/antusias/article/view/13.

Wuryantai, AG. Eka Wenats. "Digitalisasi Masyarakat: Menilik Kekuatan Dan Kelemahan Dinamika Era Informasi Digital Dan Masyarakat Informasi." Jurnal ILMU KOMUNIKASI 1, no. 2 (November 27, 2013). Accessed August 31, 2017. http://ojs.uajy.ac.id/index.php/jik/article/view/163.

Zaluchu, Sonny Eli. "Mengkritisi Teologi Sekularisasi." KURIOS (Jurnal Teologi dan Pendidikan Agama Kristen) 4, no. 1 (2018): 26-38. www.sttpb.ac.id/ejournal/index.php/kurios. 